ADDIN, Vol. 10, No. 1, Februari 2016

\title{
INTERPRETASI PAHAM RADIKALISME TERHADAP HUKUM ISLAM
}

\section{Shobirin}

STAIN Kudus, Jawa Tengah, Indonesia

shobir102@gmail.com

\section{Abstrak}

Pembatasan wilayah pengkajian dalam artikel ini, bertitik tolak dari tiga landasan keilmuan, yaitu landasan ontologi berkaitan dengan obyek kajian, landasan epistemologi berkaitan dengan metode yang digunakan dalam kajian dan landasan aksiologi berkaitan dengan kegunaan atau signifikasi kajian. Obyek kajian dalam artikel ini adalah interpretasi paham radikalisme terhadap bukum Islam, terfokus pada tiga permasalaban, yaitu interpretasi tentang hukum tagyirul munkar, interpretasi tentang bukum jïhad fi sabilillah dan interpretasi tentang bukum negara Republik. Indonesia. Metode pendekatan yang digunakan untuke pisau analisis, ada tiga yaitu; (1) pendekatan politis (political approach); (2) pendekatan perundang-undangan (statue approach); (3) pendekatan analitik (analytical approach). Bahan kajiannya adalah bahan normatif, dengan teknik kajian dokumen analisisnya bersifat deskriptif analitis (eksplanatoris). Kerangka teori yang digunakean,, yaitu pada tataran grand theory menggunakan teori ijtihad, pada tataran middle theory menggunakan teori bukum dan masyarakat dan pada dataran applied theory menggunakan teori sistem peradilan syari'ah Islam. Sedangkan signifikasi dalam kajian ini adalah untuk-menemukan penyimpangan interpretasi bukum Islam oleh paham radikalisme dan langkah-langkah dalam pembinaan atau pencegahannya.

Kata Kunci: Interpretasi, Paham Radikalisme, Hukum Islam. 
Shobirin

\section{Abstract}

INTERPRETATION OF THE RADICALISM DOCTRINE AGAINST ISLAMIC LAW: Study area restriction of this article has a starting point from the three scientific grounding. They are ontology grounding which is related to the object of study, epistemology grounding which deals with the methods used in the study, and axiology grounding which deals with the usability or the significance of the study. The object of study in this article is interpretation of radicalism doctrine against Islamic law, it focused on three issues; they are the law interpretation of tagyir al-munkar, the law interpretation of jibad fi sabilillah, and the law interpretation of the Republic of Indonesia. The approach method used for the analysis are: (1) political approach; (2) statutory approach; (3) the analytical approach. Its study material is normative material; with the study technique of document analytical is descriptive analysis (explanatory). The framework of the theory that being used, in the grand landscape theory using the theory of ijtihad, in middle of the theory using the theory of law and society and on the plains of applied theory using the theory of the judicial system of the Islamic Shariah. The significance of this study is to find interpretation irregularities of Islamic law by the doctrine of radicalism and steps in coaching or prevention.

Keywords: Interpretation, Radicalism Doctrine, Islamic Law.

\section{A. Pendahuluan}

Gerakan radikalisme merupakan fenomena dalam sejarah gerakan Islam. Ia sering muncul secara periodik, saat terjadi penyimpangan baik dalam moral, pemahaman agama, maupun pengamalan agama. Penyimpangan itu dipandanga oleh penganjur paham radikalisme sebagai kemerosotan agama dan masyarakat Islam, dan mereka menyatakan bahwa agar agama itu mencapai kejayaannya, maka agama harus dibersihkan dari segala penyimpangan, pengaburan, dan pengotoran yang berjangkit dikalangan umat Islam. Mereka melihat masyrakat semakin jauh dari ajaran Islam yang asli, para paham radikalisme kemudian menampilkan tema-tema yang menjadi acuan gerakan tersebut, yaitu mereka menganggap: (1) bahwa bid'ah dalam pelaksanaan agama telah melanda umat Islam, sehingga agama yang mereka anut bukan merupakan Islam yang benar dan 
murni, (2) praktek bid'ah terjadi akibat penyalagunaan kekuasaan tokoh-tokoh agama atau akibat pengaruh-pengaruh non Islam yang secara tidak sengaja mempengaruhi pikiran umat Islam, (3) sebagai jalan keluar dari keadaan itu, Islam harus dibersihkan dari semua prektek bid'ah dengan jalan kembali kepada alQur'an dan sunnah, (4) tipe ideal dari masyarakat yang dijadikan sebagai rujukan beragama secara murni ialah generasi salaf, yaitu mereka yang hidup pada abad-abad pertama Islam. Jadi menurut paham radikalisme bahwa generasi salaf merupakan umat terbaik sepanjang sejarah. ${ }^{1}$ Maka mereka berusaha mengembalikan pelaksanaan ajaran Islam kegenerasi salaf dengan cara amar ma'rufnahi munkar yang dipraktekkan dengan cara kekerasan (radikal).

Makna radikalisme sebenarnya, dari segi bahasa berasal dari kata dasar radix yang artinya akar pohon atau berpikir secara medasar, sampai hal yang prinsip. ${ }^{2}$ Makna kata tersebut, dapat diperluas, menjadi pegangan yang kuat, keyakinan, pencipta perdamaian dan ketenteraman. Radikal berarti lebih adjektif. Maka, orang yang berpikir radikal berarti memiliki pemahaman secara lebih detail dan mendalam, layaknya akar pohon yang kuat, serta keteguhan dalam mempertahankan kepercayaannya. Pengertian ini, terkesan tidak umum, menimbulkan kesan menyimpang di masyarakat. Radikalisme dapat diartikan secara positif, yaitu pembaharuan, perbaikan dan suatu spirit perubahan menuju kebaikan. Diharapkan dalam kehidupan berbangsa dan bernegara para pemikir radikal sebagai seorang pendukung reformasi jangka panjang. Dengan demikian makna radikalissme dapat dikembangkan, menjadi pandangan atau cara berfikir seseorang yang menginginkan peningkatan mutu, perbaikan, dan perdamaian dilingkungan yang multidimensional, hingga semua lapisan masyarakat dapat hidup rukun dan tenteram.

Namun kenyataannya, makna radikalisme itu sendiri mengalami pemelencengan makna, karena minimnya sudut pandang yang digunakan, masyarakat umum hanya menyoroti apa yang dilakukan oleh kelompok-kelompok radikal

${ }^{1}$ Syafiq A. Mughni, Nilai-nilai Islam Perumusan Ajaran dan Upaya Aktualisasi (Yogyakarta: Pustaka Pelajar, 2001), hlm.3-4.

${ }^{2}$ Prihadi, Kamus Pintar Bahasa Indonesia (Surabaya: Alfa, t.th), hlm. 291. 
(praktek kekerasan), yang salah dalam memahami agama. Sehingga radikalisme atas nama agama dimaknai sikap keras yang diperagakan oleh sekelompok penganut suatu agama, dengan dalih mengamalkan ajaran agama. Radikalisme model kekerasan dalam Islam sudah ada sejak zaman șahabat, yaitu ketika muncul kaum Khawarij setelah memuncaknya konflik antara penduku Șahabat Ali bin Abi Thalib ra. dan pendukung Șahabat Mu'awiyah ra. Kaum khawarij menganggap kedua pihak sama salah dan harus dibunuh. Mereka berhasil membunuh Sahabat Ali bin Abi Thalib ra. pada waktu subuh, tetapi tidak berhasil membunuh sahabat Mu'awiyah ra, mereka hanya bisa melukainya saja, lalu mereka tertangkap.

Sejarah keberadaan paham radikalisme tentang agama berbedabedabentuknya. Adayangterbataspadasikap radikaluntuk diri sendiri dalam melaksanakan ajaran Islam, tanpa memusuhi pihak lain yang berbeda, seperti kelompok fondamentalis yang berpendapat bahwa semua ajaran Nabi Muhammad saw. itu fondamen, atau dasar yang harus ditaati. Dilaksanakan semua perintahnya serta dijauhi semua larangannya, tanpa membeda bedakan perintah wajib atau sunnah, larangan haram atau makruh, pokoknya semua tuntunan Nabi itu fondamen, maka mereka disebut Fundamentalis. Di sisi lain ada yang lebih keras dari pada mereka, sampai mengkafirkan pihak lain yang berbeda, bahkan tega membunuh orang yang bebeda dengan mereka walaupun sesasma muslim, seperti kaum Khawarij. Padahal Islam adalah agama rạ̣matan li al-álamin artinya Islam merupakan agama yang membawa rahmat dan kesejahteraan bagi seluruh alam semesta, termasuk hewan, tumbuhan dan jin, apalagi sesama manusia. Sesuai dengan firman Allah:

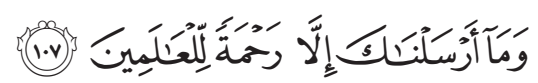

Dan tiadalah kami mengutus kamu, melainkan untuke (menjadi) rahmat bagi semesta alam. (Q.S. al-Anbiya' [21]: 107)

Indonesia adalah negara dengan penduduk muslim terbanyak di dunia. Seharusnya Indonesia menjadi negara yang indah, damai, dan beradab. Kita tidak bisa menutup mata dan telinga dengan pemberitaan sehari-hari yang mengabarkan tentang 
kisah-kisah menyedihkan dan tak beradab, yaitu tentang ledakan bom yang sasaranya ketempat-tempat ramai penuh dengan manusia. Mengapa moral mereka bekitu kejam kepada sesama manusia, jawaban sementara karena mereka tidak memahami dan menjalankan ajaran Islam secara benar. Jika mereka tahu bahwa membunuh binatang semena-mena saja dilarang oleh Islam, mana mungkin sampai berani membunuh sesama manusia.

Jika ingin merasakan Indonesia menjadi negara damai sejahtera, maka yang harus dibenahi adalah moral agama bangsa, bukan sekedar pendidikan belaka. Pendidikan moral agama yang sesungguhnya, yang komplit, dan yang diperintahkan oleh pencipta manusia adalah moral menjalankan ajaran Islam dengan benar. Setiap muslim wajib belajar dengan benar tentang agamanya. Dengan begitu kita akan mampu menjadi khalifah sesungguhnya di bumi sesuai tujuan diciptakannya manusia, yaitu menjadi rahmat bagi semesta alam.

Islam merupakan ruh dari hakekat kebenaran dan cahaya petunjuk dalam kehidupan manusia, dapat mengobati penyakit yang diderita manusia dan menghantarkannya kejalan lurus. Seperti yang dinyatakan Allah kepada Nabi Muhammad dalam firman-Nya:

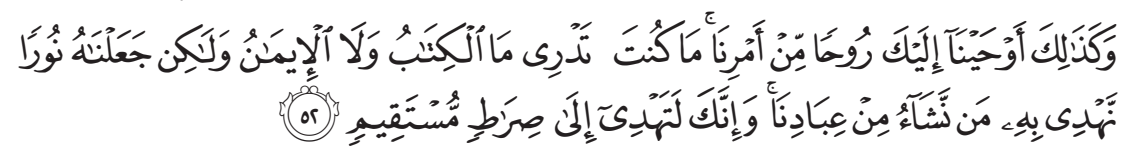

Dan Demikianlah kami wahyukan kepadamu wabyu (alQur'an) dengan perintah kami. sebelumnya kamu tidaklah mengetabui apakah al Kitab (al Qur'an) dan tidak pula mengetabui apakah iman itu, tetapi kami menjadikan al Qur'an itu cahaya, yang kami tunjuki dengan dia siapa yang kami kehendaki di antara hamba-hamba kami. dan Sesungguhnya kamu (Mubammad) benar-benar memberi petunjuk kepada jalan yang lurus. (Q.S. asy-Syura [42]: 52)

Di ayat lain dikatakan:

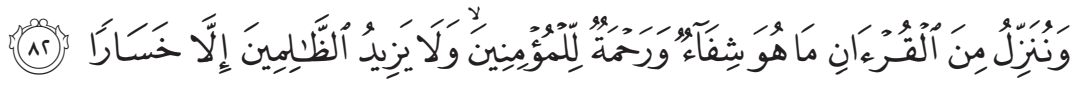
Dan kami turunkan dari al Qur'an suatu yang menjadi penawar dan rahmat bagi orang-orang yang beriman dan al Qur'an itu tidaklah menambah kepada orang-orang yang zalim selain kerugian (Q.S. alIsra’ [17]: 82.) 
Berdasarkan kedua ayat tersebut, maka dapatlah dipahami, bahwa Islam itu adalah agama tauhid, agama ilmu dan agama keadilan, yang senantiasa menegakkan hak dimana saja berada, sesuai dengan firman Allah:

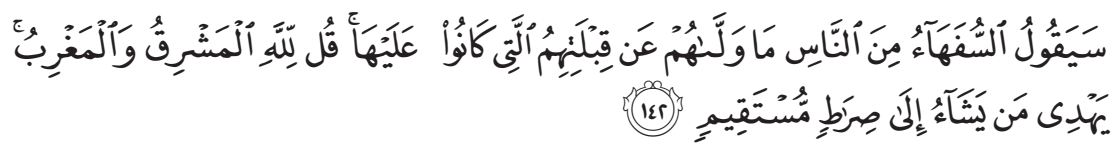

Dan demikian (pula) kami Telah menjadikan kamu (umat Islam), umat yang adil dan piliban agar kamu menjadi saksi atas (perbuatan) manusia dan agar Rasul (Mubammad) menjadi saksi atas (perbuatan) kamu. dan kami tidake menetapkan kiblat yang menjadi kiblatmu (sekarang) melainkan agar kami mengetabui (supaya nyata) siapa yang mengikuti Rasul dan siapa yang membelot. dan sunggub (pemindahan kiblat) itu terasa amat berat, kecuali bagi orang-orang yang Telah diberi petunjuk oleh Allab; dan Allah tidak akan menyia-nyiakan imanmu. Sesunggubnya Allah Maha Pengasih lagi Maha Penyayang kepada manusia (Q.S. al-Baqarah [2]: 143.)

Umat Islam dijadikan umat yang adil dan pilihan, karena mereka akan menjadi saksi atas perbuatan orang yang menyimpang dari kebenaran baik di dunia maupun di akhirat. Keadilan adalah suatu prinsip kreatif konstruktif yang selalu menjadi keutamaan moral atau akhlak. Sekalipun ada pendapat bahwa ajaran Islam yang disepakati praktek islamisasinya adalah pada zaman khalifah. Khalifah Umar adalah yang paling adil dalam pemerinthannya, maka pengalaman agama yang islami adalah penglaman adil jujur, dan menempatkan sesuatu pada tempatnya. Inilah ta'rif Islam yang sebenarnya, sesuadah arti legalnya perdamaina dan keselamatan dunia akhirat. ${ }^{3}$

Berdasarkan uraian tersebut, penulis akan mengkaji paham radikalisme, dengan judul interpretasi paham radikalisme terhadap hukum Islam, dengan mengangkat permasalahan; interpretasi tentang masalah hukum tagyirul munkar, interpretasi tentang masalah hukum jihad fi sabilillah, dan interpretasi tentang masalah hukum negara Republik Indonesia.

${ }^{3}$ Mochtar Husein, Islam itu Indah Refleksi Keimanan (Yogyakarta: Pustaka Pelajar, 2008), hlm.7-8. 


\section{B. Pembahasan}

Interpretasi diartikan sebagai proses mengubah sesuatu atau situasi ketidaktahuan menjadi mengerti. ${ }^{4}$ Sedangkan interpretasi hukum adalah proses pembentukan hukum oleh pengkaji hukum dalam penerapan hukum umum terhadap peristiwa hukum yang konkrit dan hasil interpretasi hukum menjadi dasar untuk mengambil keputusan. Penerapan interpretasi terhadap hukum selalu berhubungan dengan isinya. Setiap hukum punya dua segi, yaitu yang tersurat dan yang tersirat atau bunyi hukum dengan semangat hukum. ${ }^{5}$ Interpretasi merupakan fungsi dari hukum tertulis yang membuat rumusan-rumusan. Pembuatan hukum dan penafsiran hukum merupakan dua sisi dari barang yang sama. Teks hukum merupakan bentuk rumusan dan konseptualisasi dari sesuatu yang ada dan terjadi di alam. ${ }^{6}$

Merumuskan hukum dan membuat konsep hukum adalah pekerjaan manusia, dalam pekerjaan tersebut, akan melibatkan penilaian atau pemberian nilai. Maka hukum ada ruang kebebasan. Sementara pekerjaan manusia penuh dengan pilihan-pilihan dan juga subjektivitas. Berangkat dari kenyataan tersebut, maka akan lahir penafsiran terhadap hukum yang sudah ada. Penafsiran merupakan pekerjaan yang kreatif, inovatif dan progresif, bahkan terkadang merupakan suatu lompatan. Lompatan berarti bahwa penafsiran itu tidak lagi rulebound, melainkan keluar dari logika peraturan (logic of the rule). ${ }^{7}$

Prosedur interpretasi hukum Islam dalam memutuskan perkara, secara umum melalui beberapa tahapan, yaitu pertama musyawarah, bertujuan agar mufasir dapat mengetahui permasalahan konkret yang menjadi selisih di masyarakat. Kedua mengkualifikasi peristiwa konkret dan diterjemahkan dalam bahasa hukum Islam. Ketiga adalah mencari atau

${ }^{4}$ E Sumaryono, Hermeneutik Sebuah Metode Filsafat (Yogyakarta: Kanisius, 1993), hlm. 24.

${ }^{5}$ Amiruddin dan Jaenal Asikin, Pengantar Metodologi Hukum (Jakarta: Raja Grafindo Persada, 2004), hlm.163-164. hlm.165.

${ }^{6}$ Satjioto Rahardjo, Hukum dalam Jagat Ketertiban (Jakarta: UKI Press, 2006),

${ }^{7} \mathrm{Ibid}, \mathrm{hlm} .168$. 
menseleksi hukum dari sumber-sumber hukum Islam. Keempat menganalisis atau menginterpretasi hukum tersebut. Kelima menerapkan peraturan hukumnya terhadap peristiwa hukum dengan menggunakan silogisme. Keenam mengevaluasi dan mempertimbangkan argumentasi yang disampaikan.

Urutan enam langkah ini, bukan ketentuan harga mati, bisa dibolak balik. Namun, yang penting sifat atau sikap yang diharapkan dari setiap penafsiran hukum Islam, harus menyadari bahwa problematik hukum Islam diterapkan berpusat pada tiga hal, yaitu terlindungi tidaknya kepentingan subyek hukum yang bersangkutan, terjamin tidaknya kepastian hukum, dan tercipta tidaknya keseimbangan tatanan dalam masyarakat. ${ }^{8}$

Adanya tuntutan bahwa hukum harus dirumuskan ke dalam teks, maka hukum memasuki kebahasaan, dengan demikian hukum memasuki permainan bahasa. Di sisi lain, hukum dituntut untuk membuat rumusan-rumusan, maka hukum membangun konsep. Sedangkan konsep adalah suatu konstruksi mental, sesuatu yang tidak asli, tetapi artifisial. Dikarnakan, kontruksi dibangun dengan cara mereduksi sebuah kenyataan yang ada. Sementara, masyarakat membutuhkan ketertiban serta keteraturan dalam hidup di masyarakat. Hukum salah satu alat untuk memenuhi kebutuhan masyarakat, maka membumikan hukum Islam menjadi pekerjaan yang tidak dapat ditawar lagi, dengan cara menafsirkan terhadap teks-teks hukum Islam. Ilmu hukum Islam tidak dapat menganggap masalah penafsiran sebagai hal kecil dan dipinggirkan. Hukum tidak akan berjalan tanpa penafsiran. Hukum membutuhkan pemaknaan lebih lanjut agar menjadi lebih adil dan membumi. Membuat hukum (legislation) adalah suatu kebutuhan, sedangkan menafsirkan hukum yang sudah dibuat itu merupakan keharusan berikutnya.

Menurut hemat penulis interpretasi paham radikalisme terhadap permasalahan hukum Islam bisa dilihat dengan teori

\footnotetext{
${ }^{8}$ Sudikno Mertokusumo, Hukum Acara Perdata Indonesia (Yogyakarta: Liberty, 2002), hlm.34.

${ }^{9}$ Satjioto Rahardjo, Hukum dalam Jagat Ketertiban (Jakarta: UKI Press, 2006), hlm.166-168.
} 
ijtihad. Ijtihad merupakan sebuah konsep yang menggambarkan usaha mujtabid secara maksimal dalam penalaran, sehingga menghasilkan pendapat pribadi yang orisinil. ${ }^{10}$

\section{Interpretasi Hukum Tagyīrul Munkar}

Faktor pertama yang memicu lahirnya paham radikalisme agama dengan model kekerasan di Indonesia, yaitu dalam interpretasi hukum tagyirul munkar (mengubah kemungkaran), sebagaimana tersebut dalam hadits Nabi Muhammad saw :

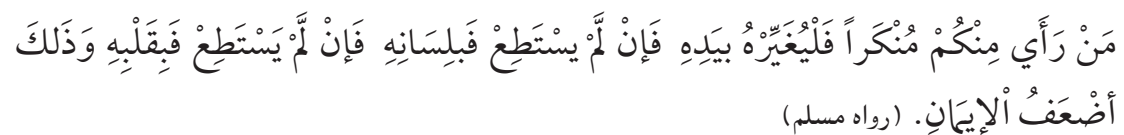

Barangsiapa di antara kamu melibat kemunkaran maka hendaklah mengubahnya dengan tangannya, lalujika tidak mampu maka dengan lisannya, lalu jilka tidak mampu maka dengan hatinya dan yang demikian itu adalah selemah - lemah iman" (H.R.Muslim).

Paham radikalisme dalam interpretasi hadis tersebut, bahwa mengubah kemunkaran dengan tangan berarti hukumnya wajib mrnghancurkan kemungkaran itu atau membunuh pelakunya. Prosedur interpretasi tersebut dapat dilihat dengan teori hukum dan masyarakat. Pada dataran middle range theory, didasarkan pada teori pragmatisme legal realism dari Roscoe Pound mengatakankan bahwa law as a tool of social engineering (hukum berfungsi sebagai sarana untuk merekayasa masyarakat ke arah tertentu yang diinginkan). ${ }^{11}$ Teori ini, didasarkan atas keyakinan bahwa : (a) antara hukum dan masyarakat terdapat hubungan yang fungsional, (b) hukum yang merupakan sistem pengaturan yang terkendali dan memaksa (coersif) berfungsi menciptakan keseimbangan antara berbagai kepentingan, (c) hukum merupakan lembaga sosial yang bersifat terencana (by design) sebagai produk kecendekiaan yang sistematis niscaya mudah disempurnakan setiap kali demi fungsional sebagai sarana social engineering, dan (d) kehidupan sosial dapat dengan mudah dipengaruhi oleh hukum manakala kepentingan mereka terjamin. Untuk memfungsikan hukum

${ }^{10}$ A. Hasan Mar'i, Al-Ijtihad fi Syari'ab al-Islamiyyah (Kairo: Mustofa Muhammad, 1976), hlm. 34.

${ }^{11}$ Roscoe Pound, Pengantar Filsafat Hukum (Jakarta: Bhatara, 1972), hlm.71. 
sebagai sarana social engineering, maka harus diciptakan hukum yang: (a) dapat menciptakan keseimbangan antara berbagai kepentingan (interest balanceing); (b) mengarahkan kehidupan sosial ke arah yang lebih baik; (c) menciptakan keadaan masyarakat yang tertib untuk mencapai cita-cita yang diinginkan; dan (d) mampu mendorong terjadinya perubahan sosial dan bahkan bila perlu dapat memaksa masyarakat untuk mengikuti norma-norma baru yang ditetapkan. Maka, hukum tidak lagi dilihat hanya sekedar tatanan penjaga status quo, tetapi sebagai sebuah sistem pengaturan untuk mencapai tujuan-tujuan tertentu secara terencana. ${ }^{12}$

Berdasarkan teori tersebut, ada kesalahan dalam interpretasi hadis, bahwa mengubah kemunkaran dengan tangan berarti wajib mrnghancurkan kemungkaran itu atau membunuh pelakunya. Padahal kalau dipahami dengan teliti, bahawa Nabi Muhammad saw sebenarnya memberikan tahapan-tahapan terhadab orang yang melaksanakan merubah kemungkaran yang disesuaikan dengan kemampuan orang yang akan melakukan merubah kemungkaran. Berarti mengubah kemunkaran dengan tangan dilakukan oleh orang yang punya kekuasaan, seperti ayah terhadap anaknya, suami terhadap istrinya, guru terhadap muridnya, terutama oleh pemerintah yang punya kekuasaan lebih luas. Dengan demikian mengubah kemunkaran dengan tangan tidak wajib dengan cara merusak apalagi membunuh pelaku kemunkaran. Sebab yang demikian itu tidak menyelesaikan masalah, justru mengundang reaksi yang membahayakan, bahkan bisa menimbulkan kemunkaran yang lebih besar.

Teori pragmatisme legal realism tersebut, kemudian dikembangkan oleh Mochtar Kusumaatmadja sebagai teori hukum pembangunan. ${ }^{13}$ Hukum yang baik harus memenuhi empat syarat, yaitu pertama, sesuai dan memperhatikan kesadaran hukum masyarakat; kedua, tidak boleh menghambat modernisasi;

${ }^{12}$ Darmodiharjo dan Sidharta, Pokok-pokok Filsafat Hukum, Apa dan Bagaimana Filsafat Hukum Indonesia (Jakarta: Gramedia, 2002), hlm. 128.

${ }^{13}$ Abdul Manan, Aspek-aspek Pengubah Hukum (Jakarta: Kencana Prenada Media. LP3ES, 2005), hlm. 21. 
ketiga, dapat menjadi sarana pembaharuan masyarakat; dan keempat, mempunyai kekuatan legalisasi dari negara. Mochtar mengemukakan bahwa hukum tanpa kekuasaan adalah anganangan dan kekuasaan tanpa hukum adalah kezaliman. ${ }^{14}$ Dengan demikian mengubah kemungkaran harus tetap dengan memperhatikan sikap bijaksana (bil-hikmah), sebagaimana kaidah hukum dikatakan:

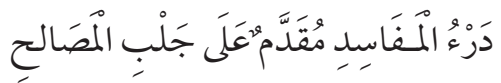

Menolak kerusakan itu didabulukan daripada menarik kebaikan. ${ }^{15}$

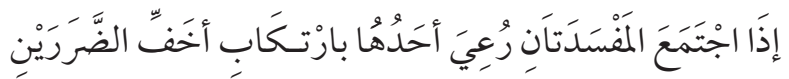

Apabila berkumpul dua mássadah (kerusakan), maka dijaga salah satu di antara keduanya, dengan menempuh yang lebih ringan bahayanya. ${ }^{16}$

\section{Interpretasi Hukum Jihad Fī Sabīlillah}

Faktor kedua yang memicu lahirnya paham radikalisme agama dengan model kekerasan di Indonesia, yaitu tentang interpretasi permasalah hukum jihad fi sabilillah, menurut mereka kata jihad tidak punya arti lain kecuali wajib perang bersenjata. Jadi semua perintah jihad dalam al-Qur'an dan hadis harus diartikan perang bersenjata, bahkan diartikan pula membunuh, yakni memerangi atau mrmbunuh orang kafir atau orang Islam yang dianggap murtad hukumnya wajib. Dalam hal ini mereka berpegang pada ayat al-Qur'an, sebagai berikut:

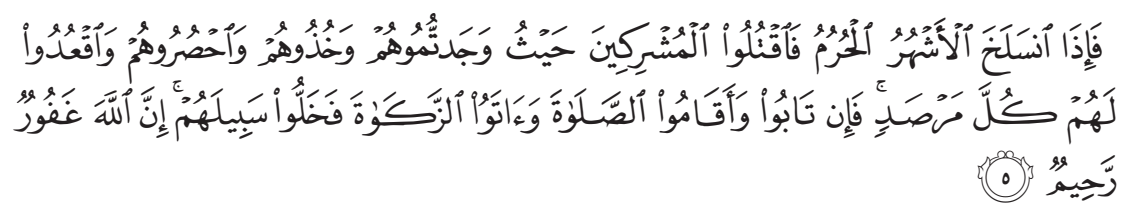

Apabila sudah habis bulan bulan haram itu, maka bunublab orangorang musyrik itu di mana saja kamu jumpai mereka, dan tangkaplah mereka, dan kepunglah mereka, dan intailah di

${ }^{14}$ Mochtar Kusumaatmadja, Fungsi dan Perkembangan Hukum dalam Pembangunan Nasional (Bandung: Bina Cipta, 1976), hlm. 11.

${ }^{15}$ Muslih Usma, Kaidah-kaidah Ushuliyyah dan Fiqhiyyah Pedoman Dasar dalam Istimbath Hukum Islam (Jakarta: Rajawali Press, 1997), hlm. 140.

${ }^{16}$ Ibid, hlm. 141. 
Shobirin

tempat pengintaian. Jika mereka bertaubatdan mendirikan shalat dan menunaikan zakat, maka berilah kebebasan kepada mereka untuk berjalan. Sesunggubnya Allah Maha Pengampun lagi Maha Penyayang. (Q.S. at-Taubah [9]: 5.)

Dan ayat yang lain dikatakan sebagai berikut:

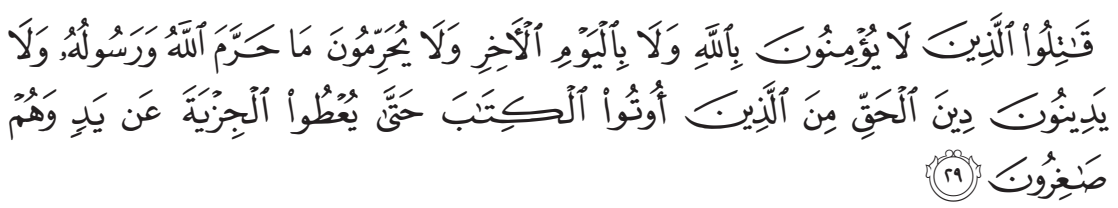

Artinya:Perangilah orangorangyang tidak beriman kepada Allah dan tidak pula kepada hari akhir, dan mereka tidak mengharamkan apa yang diharamkan Allah dan RasulNya, dan mereka tidak. beragama dengan agama yang benar,(yaitu orang orang yang) diberi al Kitab kepada mereka, sampai mereka membayar jisyah dengan patuh, sedang mereka dalam keadaan tunduk. (Q.S. at-Taubah [9]: 29.)

Disamping itu dijelaskan dalam hadis Rasulullah sebagai berikut:

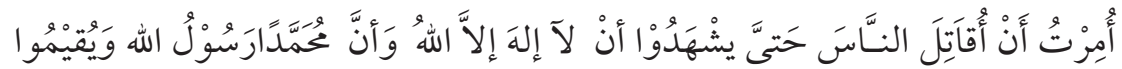

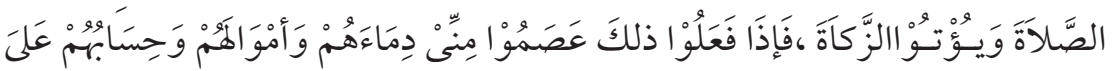

الله (رواه الشيخان)

Aku diperintah (oleh Allah) agar aku memerangi manusia sehingga mereka bersaksi bahwa tiada Tuban selain Allah dan bahwa Muhammad utusan Allah, dan mereka mendirikan shalat dan menunaikan zakat. Maka apabila mereka mengerjakan itu semua, maka mereka telah menjaga darah mereka dan harta benda mereka dari aku, dan hisabnya ada pada Allah (H.R.Bukhari dan Muslim).

Kalau dilihat sepintas, ketiga dalih tersebut sepertinya benar, dan dalilnya pun kuat. Akan tetapi apabila diperhatikan dengan seksama maka akan terlihat bahwa mereka kurang teliti dalam memahaminya, baik teks maupun konteksnya, sehingga melahirkan pandangan yang sempit, ekstrem dan radikal, dan pada gilirannya akan menimbulkan terorisme. Berkaitan dengan 
interpretasi permasalah hukum jïhad fi sabilillah oleh paham radikalisme dapat mempertimbangkan teori mashlahah (المصلحة) dari al-Syatibi dalam bukunya al- Muwafaqat, maslahah sebagai tujuan syariah harus menjadi kebijakan orang yang mengkaji hukum Islam. ${ }^{17}$

Teori maslahah ini mengajarkan bahwa a) hukum itu dibuat untuk kemaslahatan manusia, yaitu melindungi kesejahteraan agama, jiwa, akal, keturunan, dan harta kekayaan manusia, agar mendapat manfaat dan terhindar dari kerusakan. b) Apabila dalam mewujudkan kemaslahatan itu menghendaki perubahan hukum, maka hukum pun harus diubah mengikuti kemaslahatannya tersebut meskipun harus diubah mengikuti kemaslahatannya tersebut, meskipun harus menyimpang dari atau berbeda dengan teks hukumnya. c) Apabila demi terwujudnya kemaslahatan harus dibentuk hukum baru mesikupun tidak ada perintah dalam syariah. d) Apabila terjadi pertentangan atau perbedaan kemaslahatan satu sama lain, maka diambil mashlahah yang lebih besar atau kemaslahatan yang paling unggul (kuat), sesuai tujuan syariah, sehingga kemaslahatan dlaluriyat sebagai kemaslahatan sekunder, dan kemaslahatan hajiyat harus didahulukan atas kemaslahatan tahsiniyat sebagai kemaslahatan tertier. Kelima, pembentukan hukum baru melalui maslahah berdasarkan akal manusia (mursalah) tidak boleh bertentangan dengan ketentuan nash (syariah) yang bersifat ubudiyah yang menjadi hak Allah. ${ }^{18}$

Teori mashlahah ini dapat diterapkan dalam istimbat hukum atau interpretasi permasalahan hukum jihad fi sabilillah apabila dipenuhi 4 (empat) syarat, yaitu : (a) keadaanya sudah mencapai tingkat dharuriyat di mana kemaslahatannya sangat esensial dan primer; (b) kemaslahatannya bersifat qath'iyyah, yakni sangat jelas dan tegas; (c) kemaslahatan tersebut bersifat kuliyah (universal); dan (d) kemaslahatan tersebut berdasarkan dalil-dalil (alasan-

\footnotetext{
t.th), hlm.7.

${ }^{17}$ Al-Syathibi, Al-Muafaqat fi Usulal-Syari'ah (Kairo: Mustafa Muhammad,

${ }^{18}$ A. Mukti Arto, Peradilan Agama dalam Sistem Ketatanegaraan Indonesia (Yogyakarta: Pustaka Pelajar, 2012), hlm.21.
} 
alasan) yang mu'tabarah (dalil universal) dari keseluruhan qarinah, pendapat al Syatibi yang dikutip oleh Hamka Haq. ${ }^{19}$

Berdasarkan teori tersebut, kesalahan paham radikalisme dalam menafsirkan dua ayat dan satu hadits tadi, yaitu bahwa orang kafir harus diperangi sehingga mereka masuk Islam, jadi kepada orang kafir hanya diberi dua opsi: masuk Islam atau dibunuh. Bahkan mereka berpendapat bahwa berdasar ayat lima surat at-Taubah tersebut seorang muslim boleh membunuh orang kafir di mana pun mereka berada. Ayat ini disebut ayatus saif atau ayat pedang. Semua ayat yang bertentangan atau berbeda dengan ayat ini dianggap mansukh (dihapus hukumnya).

Kenyataannya kata jihad tidak hanya mempunyai arti perang bersenjata, di dalam al-Qur'an dan hadis terdapat banyak kata jihad yang berarti berjuang dengan dakwah, seperti firman Allah:

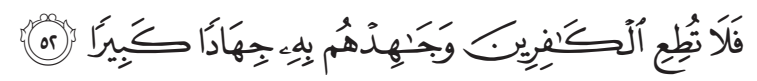

Maka janganlah kamu mengikuti orang orang kafir, dan berjihadlah kamu dengan al-Qur'an, dengan jibad yang besar" (Q.S. al-Furqan [25]: 52.)

Ayat ini termasuk kategori ayat Makiyyah, di mana waktu itu belum ada perintah perang bersenjata, jadi kata jihad dalam ayat ini diartikan berjuang dengan dakwah menyebar luaskan alQur'an. Bahkan jihad dengan dakwah dalam ayat ini disebut sebagai jihad besar. Dalam hadis juag dikatakan;

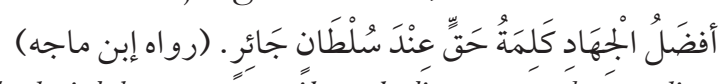

Seutama utama jihad ialah menyampaikan kalimat yang beñar di badapan kepala Negara yang dhalim” (H.R.Ibnu Majjah).

Jihad dalam arti perang bersenjata dalam Islam tidak dilakukan oleh perorangan, melainkan harus dengan ijin sultan (kepala Negara), dengan dua alasan sebagai berikut, yaitu membela diri dari serangan orang kafir musuh (kafir harbi), baik serangan itu sudah terjadi atau pasti akan terjadi, sesuai dengan firman Allah:

${ }^{19}$ Hamka Haq, Al-Syatibi Aspek Teologis Konsep Mashlalah dalam Kitab alMunvafaqat (Jakarta: Erlangga, 2007), hlm. 250-251. 


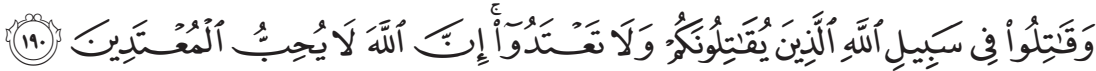

perangilah di jalan Allah orang-orang yang memerangi kamu, (tetapi) janganlah kamu melampaui batas, Karena Sesunggubnya Allah tidak menyukai orang-orang yang melampaui batas". (Q.S. al-Baqarah [2]: 190 )

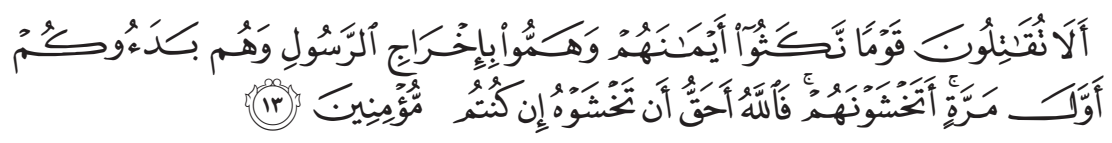

Mengapakah kamu tidak memerangi orang-orang yang merusak. sumpah (janjinya), padahal mereka Telah keras kemanannya untuk. mengusir Rasul dan merekalah yang pertama mulai memerangi kamu?. mengapakah kamu takut kepada mereka padahal Allah-lahyang berhak untuk kamu takuti, jika kamu benar-benar orangyang beriman"” (Q.S. at-Taubah [9]: 13)

Berdasarkan surat al-Baqarah [2]: 190 dan Q.S. at-Taubah [9]: 13 tersebut, jihad berarti dalam rangka melindungi pelaksanaan dakwah Islamiyah dari gangguan keamanan orang-orang yang tidak suka akan tersebarluasnya ajaran Islam.Jadikalau berdakwah tidak diganggu, maka tidak perlu ada perang, karena pada dasarnya dakwah hanya dilkasanakan sesuai dengan tuntunan Allah dan Rasulnya, tanpa paksaan, tanpa kekerasan, sebagaimana firman Allah:

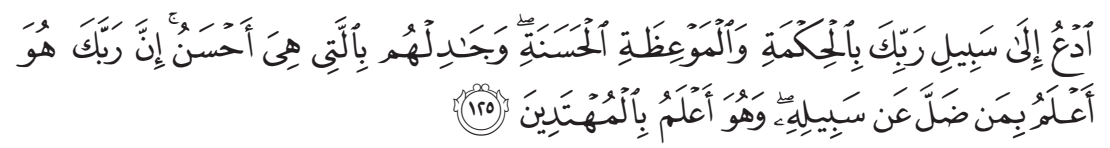

Serulah (manusia) kepada jalan Tuhan-mu dengan hikmah dan pelajaran yang baik dan bantablah mereka dengan cara yang baik. Sesunggubnya Tuhanmu dialah yang lebih mengetahui tentang siapa yang tersesat dari jalan-Nya dan dialah yang lebih mengetahui orang-orang yang mendapat petunjuk (Q.S. an-Nahl [16]: 125.)

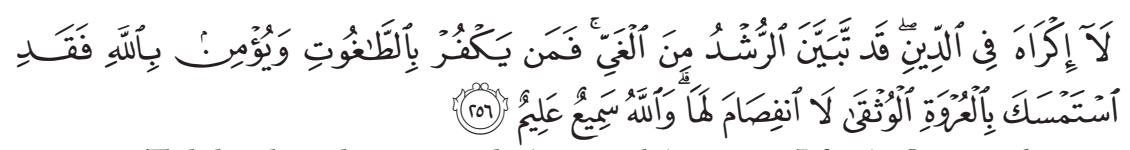

Tidak ada paksaan untuk (memasuki) agama (Islam); Sesunggubnya Telab jelas jalan yang benar daripada jalan yang sesat. Karena itu barangsiapa yang ingkar kepada Thaghut dan beriman kepada Allah, 
Shobirin

Maka Sesunggubnya ia Telab berpegang kepada bubul tali yang amat Kuat yang tidak akan putus. dan Allah Maha mendengar lagi Maha Mengetahui (Q.S. al-Baqarah [2]: 256.)

Dengan demikian, tidak benar bahwa dalam surat Q.S. at-Taubah [9]: 5 dan Hadis riwayat Bukhari dan Muslim di atas menyuruh orang Islam membunuh orang orang kafir di mana pun mereka berada tanpa sebab, dan orang orang kafir hanya diberi dua opsi, masuk Islam atau kalau tidak mau masuk Islam dibunuh, yang berarti mereka dibunuh atau diperangi itu karena kekafirannya. Padahal banyak ayat al-Qur'an dan Hadits Nabi yang menunjukkan bahwa bagi orang orang kafir tersedia beberapa opsi, dan mereka diperangi bukan karena kekafirannya, tetapi karena mereka memerangi orang Islam. Penjelasannya dalam ayat-ayat al-Qur'an sebagai berikut:

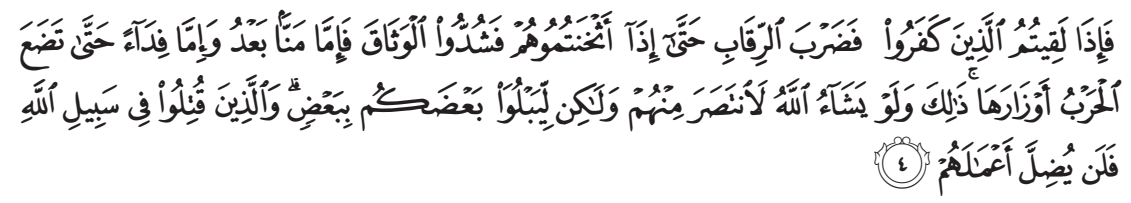

Apabila kamu bertemu dengan orang-orang kafir (di medan perang) Maka pancunglab batang leher mereka. sehingga apabila kamu Telah mengalabkan mereka Maka tawanlah mereka dan sesudah itu kamu boleh membebaskan mereka atau menerima tebusan sampai perang berakbir. Demikianlah apabila Allah menghendaki niscaya Allah akan membinasakan mereka tetapi Allah hendak menguji sebahagian kamu dengan sebahagian yang lain. dan orang-orang yang syahid pada jalan Allah, Allah tidak akan menyia-nyiakan amal mereka (Q.S. Muhammad [47]: 4.)

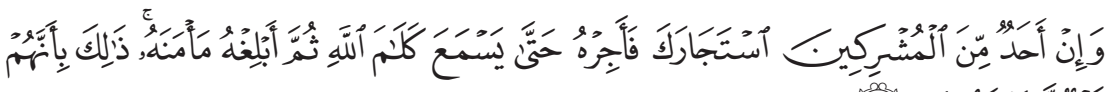

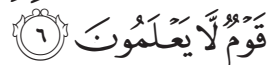

Dan jika seorang diantara orang-orang musyrikin itu meminta perlindungan kepadamu, Maka lindungilah ia supaya ia sempat mendengar firman Allah, Kemudian antarkanlah ia ketempat yang aman baginya. demikian itu disebabkan mereka kaum yang tidak. Mengetabui Q.S. at-Taubah [9]: 6.)

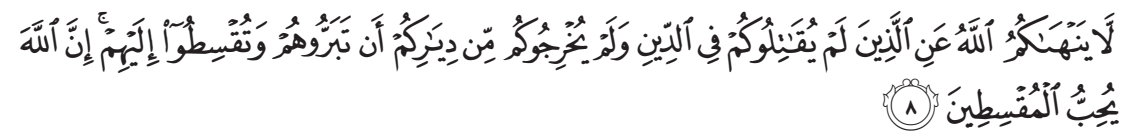


Allah tidak melarang kamu untuk berbuat baik dan berlaku adil terhadap orang-orang yang tiada memerangimu Karena agama dan tidak (pula) mengusir kamu dari negerimu. Sesunggubnya Allah menyukai orang-orang yang berlaku adil (Q.S. Mumtahanah [60]: 8.)

Menurut pendapat penulis bahwa, berdasarkan teori maslahah ini dapat diterapkan dalam menafsirkan hukum Islam secara proposional. Prosedur yang harus dilakukan oleh paham radikalisme dalam interpretasi masalah hukum jibad fi sabilillah adalah sebagai berikut: (a) Dalam hal-hal yang berkaitan dengan bukum wad'i (yakni, hukum yang berfungsi melindungi hak-hak Tuhan, hak-hak publik, ketertiban umum, kepastian hukum, dan nilai-nilai kebenaran), maka kepastian hukum harus diutamakan. (b) Dalam hal-hal yang berkaitan dengan hukum taklifi (yakni, hukum yang mengatur hak dan kewajiban antar subjek hukum atau mukallaf), maka rasa keadilan harus diutamakan. (c) Dalam hal terjadi kontradiksi (perbenturan) antara kepastian hukum dan rasa keadilan, maka diterapkan teori maslahah, yakni manfaat yang lebih luas. (d) Demikian pula jika terjadi pertentangan kemaslahatan satu sama lain, maka diambil maslahah yang lebih besar, sesuai tujuan syariah Islam. Empat prosedur tersebut, tidak ada satu pun yang dilakukan oleh paham radikalisme.

\section{Interpretasi Tentang Masalah Hukum Negara Republik Indonesia}

Faktor ketiga yang memicu lahirnya paham radikalisme agama dengan model kekerasan di Indonesia, yaitu tentang interpretasi permasalah hukum negara kesatuan Republik Indonesia bukan negara Islam (bukan Därul Islam) melainkan negara kafir (därul kufriatau därul harbi), alasann merka, yitu; bahwa hukum yang diberlakukan di Indonesia bukan hukum Islam, melainkan Pancasila, UUD 45 dan KUHAP/KUHP warisan penjajah kafir Belanda, sistim pemerintahannya mengikuti tatanan pemerintahan kafir dengan sistim trias politika, bukan sistim kekhilafahan dan kepala negara bukan kholifah, yang ditetapkan berdasarkan suara terbanyak dalam pemilihan umum. Dasar yang dipakai oleh mereka adalah interpretasi terhadap ayat al-Qur'an sebagai berikut: 
Shobirin

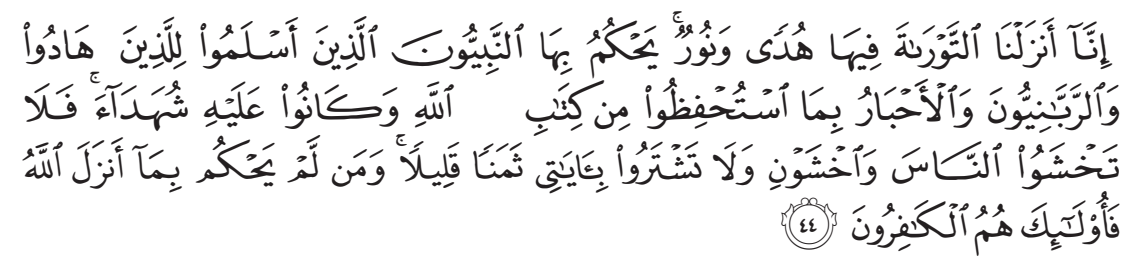

Sesunggubnya kami Telah menurunkan Kitab Taurat di dalamnya (ada) petunjuk dan cabaya (yang menerangi), yang dengan Kitab itu diputuskan perkara orang-orang Yahudi oleh nabi-nabi yang menyerah diri kepada Allah, oleh orang-orang alim mereka dan pendeta-pendeta mereka, disebabkan mereka diperintahkan memelihara kitab-kitab Allah dan mereka menjadi saksi terhadapnya. Karena itu janganlah kamu takut kepada manusia, (tetapi) takutlah kepada-Ku. dan janganlah kamu menukar ayat-ayat-Ku dengan harga yang sedikit. barangsiapa yang tidak memutuskan menurut apa yang diturunkan Allah, Maka mereka itu adalah orang-orang yang kafir. (Q.S. al-Ma'idah [5]: 44.)

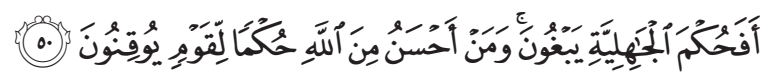

Apakah bukum Jahiliyah yang mereka kehendaki, dan (bukum) siapakah yang lebih baik daripada (bukum) Allah bagi orang-orang yang yakin? (QS. Al-Maidah/5:50).

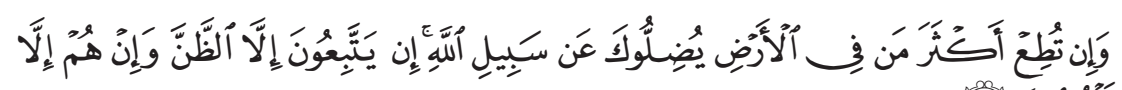

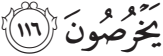

Dan jika kamu menuruti kebanyakan orang-orang yang di muka bumi ini, niscaya mereka akan menyesatkanmu dari jalan Allah. mereka tidak lain hanyalah mengikuti persangkaan belaka, dan mereka tidak lain hanyalah berdusta (terhadap Allah). (Q.S. al-An'am [6]: 116.)

Pemerintahannya mengikuti tatanan pemerintahan kafir dengan sistim trias politika, bukan sistim kekhilafahan dan kepala negara bukan kholifah, yang ditetapkan berdasarkan suara terbanyak dalam pemilihan umum. Dasar yang dipakai oleh mereka adalah interpretasi terhadap ayat al-Qur'an sebagai berikut:

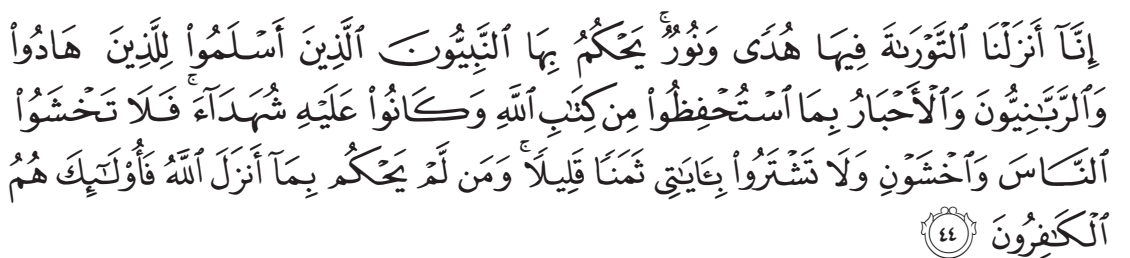


Sesunggubny a kami Telah menurunkan Kitab Taurat di dalamnya (ada) petunjuk dan cahaya (yang menerangi), yang dengan Kitab itu diputuskan perkara orang-orang Yabudi oleh nabi-nabi yang menyerah diri kepada Allah, oleh orang-orang alim mereka dan pendeta-pendeta mereka, disebabkan mereka diperintabkan memelihara kitab-kitab Allah dan mereka menjadi saksi terhadapnya. Karena itu janganlah kamu takut kepada manusia, (tetapi) takutlah kepada-Ku. dan janganlah kamu menukar ayat-ayat-Ku dengan harga yang sedikit. barangsiapa yang tidak. memutuskan menurut apa yang diturunkan Allah, Maka mereka itu adalah orang-orang yang kafir (Q.S al-Ma'idah [5]: 44.)

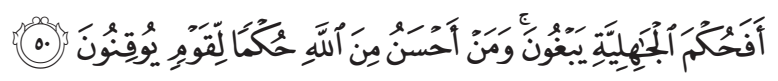

Apakah bukum Jabiliyah yang mereka kehendaki, dan (bukum) siapakah yang lebih baik daripada (bukum) Allah bagi orang-orang yang yakin? (Q.S al-Ma’idah [5]: 44)

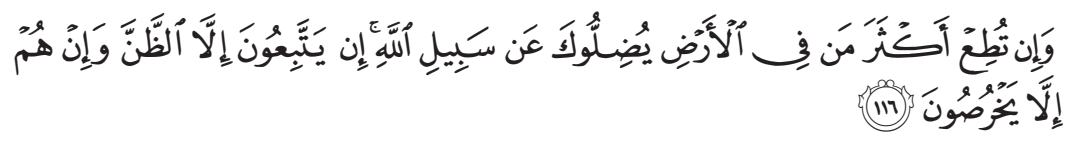

Dan jika kamu menuruti kebanyakan orang-orang yang di muka bumi ini, niscaya mereka akan menyesatkanmu dari jalan Allah. mereka tidak lain hanyalah mengikuti persangkaan belaka, dan mereka tidak lain hanyalah berdusta (terhadap Allah) (Q.S. al-An'am [6]: 116.)

Mereka kurang teliti dalam memahami ayat-ayat tersebut, baik teks maupun konteksnya, sehingga melahirkan pandangan yang sempit, ekstrem dan radikal, dan pada gilirannya akan menimbulkan terorisme. Negara Kesatuan Republik Indonesia; sebelum di jajah oleh Portugis, Belanda dan Jepang, Indonesia di bawah kekuasaan para sultan Islam; sekitar 40 kesultanan Islam. Selama masa penjajahan umat Islam berjuang dan terus berjuang untuk merebut kemerdekaan dari kekuasaan penjajah. Sampai akhirnya berhasil dan merdeka pada tanggal9Ramadan 1334 H/17 Agustus 1945 M. Menurutsebagian pendapat para ulama negara Islam yang dijajah oleh orang kafir, 
tetap dianggap Därul Islam, apalagi Indonesia sudah berhasil direbutnya kembali dari kekuasaan penjajah kafir, dan sekarang dikuasai penuh oleh rakyat Indonesia yg mayoritasnya beragama Islam, kepala Negaranya beragama Islam, umat Islam di Indonesia dapat mengamalkan ajaran Islam serta menegakkan syi'ar Islam, meskipun belum bisa memberlakukan hukum Islam secara penuh.

Permasalahan tersebut, dapat dilihat dengan teori sistem peradilan syari'ah Islam sebagai applied theory merupakan teori praktis dalam pembentukan dan penyelenggaraan peradilan syariah Islam. Teori ini menyajikan konsep bagaimana membentuk Peradilan Agama yang berkompenten dalam menangani permasalahan umat Islam dalam bidang hukum Islam. Negara Indonesia memiliki Peradilan Agama sesuai dengan kehidupan ketatanegaraan Indonesia berdasarkan UUD 1945, dibentuk dan diselenggarakan berdasarkan prinsip-prinsip syariah Islam, dapat dipercaya dan mampu melakukan tugas pokok dan fungsinya secara tuntas, dan mampu melayani perkembangan kebutuhan hukum dan keadilan bagi masyarakat pencari keadilan berdasarkan syariah Islam.

Muhammad Salam Madkur dalam bukunya al-Qada fi al Islam mengatakan bahwa peradilan syariah Islam memiliki ciriciri sebagai berikut: (a) Menegakkan peradilan adalah wajib; (b) Menegakkan peradilan merupakan sunnah (praktik kehidupan) Nabi Muhammad SAW yang harus diikuti; (c) Menegakkan peradilan untuk menyelesaikan sengketa antar umat manusia; (d) Menegakkan peradilan untuk menegakkan hukum agama dan mencegah penyelewangan; (e) Harus ada kekuasaan yang mengawawsi dan mengatur jalannya pengadilan; (f) Pengadilan memiliki kekuatan dan kekuasaan (kompetensi) untuk memeriksa dan mengadili perkara; (g) Pengadilan harus memiliki kewibawaan; (h) Pengadilan harus dapat memulihkan kembali hak pihakpihak yang dirugikan (didzalimi), dan memulihkan kembali situasi keamanan dan ketertiban; (i) Pengadilan merupakan bagian dari kekuasaan negara; (j) Rakyat harus tunduk pada putusan pengadilan; (k) Pengadilan harus mandiri dan berdiri 
sendiri secara khusus; (l) Pengadilan harus independen dan tidak memihak; (m) Pengadilan merupakan lembaga yang agung nilainya; (n) Orang yang cakap dan memenuhi syarat wajib menjadi hakim; (o) Pengadilan mampu memberi rasa bangga dan puas; (p) Pengadilan tampil berwibawa, terpercaya, terhormat, dan menyejukkan; (q) Pengadilan mampu memberi pelayanan prima; dan (r) Pengadilan mampu menjamin kepastian hukum dan tertib hukum melalui administrasi peradilan. ${ }^{20}$

Melengkapi teori peradilan syariah Islam dari Salam Madkur tersebut, Hasbi ash-Shiddieqy, mengatakan bahwa Peradilan Syariah Islam memiliki ciri-ciri sebagai berikut : (a) Peradilan merupakan sebuah sistem yang dibentuk dan diselenggarakan oleh penguasa atau khalifah (negara) sehingga tampil sebagai pengadilan negara untuk memenuhi perintah agama Islam dan/ atau memenuhi kebutuhan umat Islam, (b) Peradilan merupakan bagian dari dan takterpisahkan dalam pengamalan Agama Islam dan kehidupan ketatanegaraan berdasarkan prinsip-prinsip syariah Islam, (c) Peradilan merupakan simbol syariah Islam; (d) Peradilan berfungsi memberi pelayanan hukum dan keadilan berdasarkan syariah Islam; menegakkan dan mengembangkan hukum syariah Islam serta menyelesaikan sengketa antara pihak-pihak yang berperkara; (e) Peradilan bertumpu pada asas personalitas keislaman, asas rahmatan lil 'alamin dan penghargaan terhadap hak asasi manusia, (f) Pengadilan mampu menegakkan hukum syariah Islam berdasarkan asas personalitas keislaman secara utuh dan sempurna, (g) Peradilan merupakan tugas pokok dan berkedudukan tinggi, (h) Wajib atas kepala negara mengangkat qadli (hakim) untuk menyelesaikan perkara-perkara yang menurut hukum harus melalui putusan hakim, guna menyejahterakan masyarakat, (i) Menjadi hakim hukumnya adalah fardlu kifayah, (j) Peradilan syariah Islam merupakan suatu lembaga yang harus dibina dengan sempurna dalam tiap-tiap negara. ${ }^{21}$

${ }^{20}$ M. Salam Madkur, AlQada' fiy al Islam (Kairo : Dar al-Nahdhah al-Arabiyah, t.th), hlm. 66-72.

${ }^{21}$ Hasbi Ash Shiddieqy, Hasbi, Peradilan dan Hukum Acara Islam (Semarang: Pustaka Rizki Putra, 1997), hlm. 34. 
Baqir Manan mengatakan bahwa pengadilan negara hanya dibentuk dan diselenggarakan oleh negara atau atas nama negara. ${ }^{22}$ Sesuai dengan tugasnya mengawal dan menegakkan hukum syariah Islam, maka kompetensi peradilan syariah Islam adalah diperoleh dari syariah Islam itu sendiri dan seluas syariah Islam guna menegakkan hukum dan keadilan sesuai dengan situasi dan kondisi masyarakat berdasarkan prinsip rahmatan lil 'alamin mampu mendamaikan dan memulihkan kembali hubungan sosial antara pihak-pihak yang bersengketa; mampu melaksanakan sendiri keputusan-keputusannya; mampu mengatasi segala hambatan dan rintangan dalam rangka pelayanan hukum dan keadilan; dan mampu tampil sebagai Peradilan Syariah Islam yang seutuhnya dan andal dan sekaligus sebagai Peradilan Negara yang sesungguhnya. Abdul Karim Zaidan dan Abu Bakar ibn Mas'ud menyatakan bahwa hukum mengangkat qadli adalah fardu (wajib). ${ }^{23}$

Menurut penulis berdasarkan dua teori peradilan syariah Islam tersebut, yakni dari Salam Madkur dan Hasbi Ash Shiddieqy, kemudin digabung dan diramu menjadi sebuah konsep Peradilan Syariah Islam sebagai applied theory, maka Peradilan Agama di Indonesia berkompeten dalam menangani perkara hukum keluarga Islam dengan bukti : pertama, tampil menjadi Pengadilan Negara yang sesungguhnya sesuai kehidupan ketatanegaraan menurut UUD 1945; kedua, memiliki kelembagaan dalam sistem ketatanegaraan Indonesia yang sesuai dengan kehidupan ketatanegaraan menurut UUD 1945 dan prinsip-prinsip syariah Islam; dan ketiga, tampil sebagai peradilan syariah Islam yang seutuhnya.

Sedangkan berkaitan dengan hukum kafir bagi yang tidak memberlakukan hukum Islam, seperti tersebut dalam surat alMaidah ayat 44 tersebut, perlu dicari pejelasannya, sebab ada dua ayat berikutnya yang berbeda thesisnya, yaitu:

${ }^{22}$ Bagir Manan, Kekuasaan Kehakiman Indonesia dalam UU No.4 Tabun 2004 (Yogyakarta: FH UII Press, 2007), hlm. 34.

${ }^{23}$ Abdul Karim Zaedan, Nižam AlQada' Fì al Syariat al Islamiyah (Baghdad: Aniy, 1984), hlm.33. 


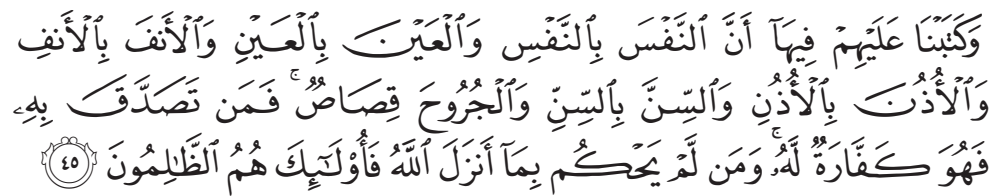

Dan kami Telah tetapkan terhadap mereka di dalamnya (At Taurat) bahwasanya jiwa (dibalas) dengan jiwa, mata dengan mata, bidung dengan hidung, telinga dengan telinga, gigi dengan gigi, dan luka luka (pun) ada kisasnya. barangsiapa yang melepaskan (hak kisas) nya, Maka melepaskan hak itu (menjadi) penebus dosa baginya. barangsiapa tidak memutuskan perkara menurut apa yang diturunkan Allah, Maka mereka itu adalah orang-orang yang zalim (Q.S. al-Ma'idah [5]: 45.)

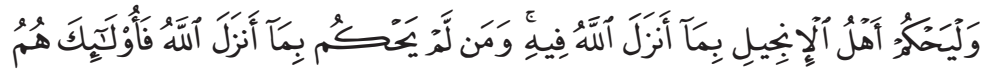

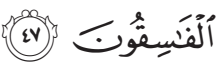

Dan hendaklah orang-orang pengikut Injil, memutuskan perkara menurut apa yang diturunkan Allah didalamnya. barangsiapa tidak memutuskan perkara menurut apa yang diturunkan Allah, Maka mereka itu adalah orang-orang yang fasike (Q.S. al-Ma'idah [5]: 47)

Ayat tersebut menjelaskan bahwa jika seseorang yang tidak memberlakukan hukum Allah, dan meyakini bahwa hukum Allah itu tidak baik, dan menganggap ada hukum selain hukum Allah itu lebih baik, maka dia kafir. Sementara jika seseorang meyakini bahwa hukum Allah itu baik, tetapi dia tidak senang memberlakukan hukum Allah karena mengikuti hawa nafsunya, maka dia zalim dan fasiq. Sedangkan jika seorang meyakini bahwa hukum Allah itu baik dan benar, lalu dia berusaha memberlakukannya, akan tetapi belum berhasil, lalu dikompromikan dengan hukum selain hukum Allah, demi kemaslahatan umat serta menjaga agar tidak timbul madarat yang lebih besar, maka dia tidak kafir, tidak zalim dan fasiq, selagi mereka tetap mengusahakan berlakunya hukum Allah. Apa yang diperintahkan oleh Allah dan RasulNya, hendaklah dilaksanakan sesuai dengan kemampuan, sebagaimana firman Allah :

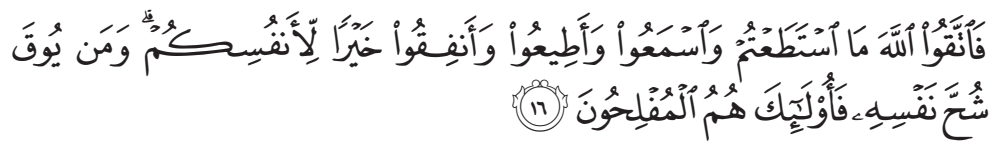


Maka bertakwalah kamu kepada Allah menurut kesanggupanmu dan dengarlah serta taatlah dan nafkahkanlah nafkah yang baik untuk. dirimu dan barangsiapa yang dipelihara dari kekikiran dirinya, Maka mereka Itulah orang-orang yang beruntung (Q.S. at-Tagabun [64]: 16.)

Dalam masalah penafsiran ini, dapat dilihat dengan teori transformasibukumsyariabIslam yang dikemukakan oleh Mohammad Hatta, Negara Indonesia yang kemudian memakai semboyan Bhineka Tunggal Ika, tiap-tiap peraturan dalam kerangka syariah Islam, yang hanya mengenai orang Islam, dapat dimajukan sebagai rencana UU ke DPR, yang setelah diterima oleh DPR mengikat umat Islam Indonesia. Dengan cara begitu lambat laun terdapat bagi umat Islam Indonesia suatu sistem syariah Islam yang teratur dalam UU, berdasarkan al-Qur'an dan hadis, yang sesuai pula dengan keperluan masyarkat Islam sekarang. ${ }^{24}$

Pernyataan Mohammad Hatta ini, akhirnya menjadi kebijakan politik Pemerintah Indonesia terhadap hukum syariah Islam, yaitu politik transformasi hukum syariah Islam menjadi peraturan perundang-undngan, sehingga membentuk suatu sistem hukum syariah Islam menjadi peraturan perundangundangan yang : (a) Berdasarkan Akidah Tauhid; (b) Bersumber dari al-Qur'an dan hadis, (c) Telah disepakati bersama secara demokratis melalui wakil-wakil rakyat di DPR; (d) Ditransformasi ke dalam bentuk peraturan perundang-undangan sehingga menjadi hukum positif yang mengikat umat Islam Indonesia; dan (e) Sesuai dengan perkembangan kebutuhan hukum masyarakat Islam Indonesia. Menurut Anwar Haryono, hukum Islam itu bersumber dari wahyu dan pemikiran manusia. ${ }^{25}$ Menurut Musa Asy'ari diistilahkan sebagai hasil berpikir rasional tansendental yang berpijak pada kitab dan hikmah, dan inilah ciri khas pemikiran dalam Islam. ${ }^{26}$. Jadi, hukum yang tepat bagi masyarakat muslim Indonesia adalah hukum syariah Islam. Hal ini tanpa

${ }^{24}$ Salman al-Farisi, Mohammad Hatta Biografi Singkat 1902-1980 (Yogyakarta: Garasi, 2009), hlm. 154.

${ }^{25}$ Anwar Haryono, Hukum Islam Keadilan dan Keluasannya (Bandung: Bulan Bintang, 2004), hlm. 93.

${ }^{26}$ Musa Asy'ari, Filsafat Islam Sunnah Nabi dalam Berpikir (Yogyakarta: LESFI, 2002), hlm. 21. 
mengurangi kemerdekaan umat beragama lain untuk beribadah menurut agamanya sesuai dengan UUD 1945.

Berkaitan dengan sistim pemerintahan yang trias politika, kepala Negara bukan khalifah, ditetapkan berdasarkan suara terbanyak, pada zaman Nabi Muhammad saw kekuasaan legislatif, eksekutif dan yudikatif semua ditangan Nabi Muhammad langsung, tetapi tidak ada larangan untuk memisahkan ketiga kekuasaan tersebut karena kondisi yang berbeda. Pada zaman kholifah Abu Bakar ra. sebahagian kekuasaan legislativ sudah tidak lagi di tangan kholifah, sebab hukum tinggal mengambil dari al-Qur'an dan Haditas, ditambah dengan hasil ijtihad beliau sendiri. Jadi tidak ada masalah dengan trias politika sebab memang tidak ada larangan.

Sedangkan berkaitan dengan sebutan khalifah, Islam tidak menentukan sebutan tertentu bagi kepala negara, ini terbukti ketika Rasulullah saw, wafat diganti Abu Bakar r.a. beliau disebut Khalifatu Rosulillah. Setelah diganti Umar bin Khattab beliau minta dipanggil Amirul Mukminin. Sesudah itu ada yang dipanggil Sultan, maka kiranya tidak salah kalau kemudia ada yang disebut Presiden. Tentang penetapan kepala negara, menurut ijmak ulama hukumnya wajib, tetapi tentang tata cara penetapan kepala negara tidak ada ketentuan yang pasti dan yang harus diikuti. Terbukti dari cara penetapan khalifah Abu Bakar r.a.yang berbeda dengan cara penetapan khalifah Umar bin Khattab r. a., dan berbeda pula dengan cara penetapan khalifah Usman bin 'Affan ra. Tentang demokrasi yang didasarkan pada suara terbanyak; Nabi Muhammad saw. bersabda: ikutilah (nuktah) hitam yang terbesar (maksudnya suara terbanyak). Pada waktu akan perang Uhud, Nabi saw. berpendapat sebaiknya orang orang Islam menunggu kedatangan musuh di dalam kota Madinah, tetapi suara terbanyak menghendaki agar orang orang Islam menjemput musuh di luar kota agar tidak terjadi kerusakan dalam kota Madinah. Maka Nabi mengikuti suara terbanyak, yaitu menjemput musuh di luar kota Madinah. Jadi tidak ada masalah dengan penetapan keputusan berdasar suara terbanyak, selagi tidak ada ketetapan hukum yang sudah pasti. 
Sampai di sini dapat diambil kesimpulan bahwa telah terjadi kesalah pahaman atau terjadi pemahaman yang sepotong sepotong terhadap dalil naqli dari al-Qur'an dan hadiss Nabi Muhammad saw.

\section{Simpulan}

Secara garis besar hukum Islam mengandung dua dimensi, (1) berkaitan dengan syariat yang mengandung nas yang qat? $i$ berlaku universal dan menjadi asas pemersatu dan mempolakan arus utama aktivitas umat Islam sedunia, (2) berakar pada nas zanni yang merupakan wilayah ijtihad, di mana hasil dari ijtihad tersebut disebut fiqh. ${ }^{27}$ Secara sosiologis, hukumIslam merupakan refleksi tata nilai yang diyakini masyarakat sebagai suatu pranata dalam kehidupan bermasyarakat, berbangsa, dan bernegara. Ini berarti, muatan hukum selayaknya mampu menangkap aspirasi masyarakat yang tumbuh dan berkembang, bukan hanya yang bersifat kekinian, melainkan juga sebagai acuan dalam mengantisipasi perkembangan sosial, ekonomi, dan politik di masa depan. Hukum bukan sekedar norma statis yang mengutamakan kepastian dan ketertiban, melainkan juga normanorma yang harus mampu mendinamisasikan pemikiran dan merekayasa perilaku masyarakat dalam mencapai cita-citanya (law as a tool of social engineering). Secara teologis hukum Islam adalah sistem hukum yang bersifat Illahiyah dan transenden. Akan tetapi dilihat dari perspektif sosiologis, ia merupakan fenomena peradaban, kultur dan realitas sosial kehidupan manusia. Pada level sosial, hukum Islam tidak saja sekedar doktrin yang bersifat universal. Tetapi juga mengejawantah diri dalam institusiinstitusi sosial yang dipengaruhi oleh situasi dan dinamika ruang dan waktu. ${ }^{28}$ Kedudukan hukum Islam yang demikian memusat dan universal jangkauannya tidak hanya sekedar menentukan pandangan hidup dan tingkah laku para pemeluknya saja, tetapi ia justru menjadi penentu utama bagi pandangan hidup

${ }^{27}$ Amrullah Ahmad SF (ed), Dimensi Hukum Islam dalam Sistem Hukum Nasional (Jakarta: Gema Insani Pers, 1996), hlm. 20.

${ }^{28}$ Azumardi Azra, Pergolakan Politik Islam dari Fundamentalisme, Modernisme, Hingga Post-Engineering (Jakarta: Paramadina, 1996), hlm. 45. 
yang dimaksud. ${ }^{29}$ Sehingga hukum Islam yang mengandung nilai-nilai yang bersifat universal pada tingkat sosial tidak dapat menghindarkan diri dari sebuah realitas yakni perubahan yang menjadi karakter dasar kehidupan sosial.

Terjadinya kesalah pahaman kaum radikalisme terhadap hukum Islam sehingga melahirkan sikap radikal dan terorisme. Karena, semangat tinggi untuk memperjuangkan Islam, tetapi kurang pertimbangan, sebab kurangnya ilmu pengetahuan tentang hukum Islam, pemahaman terhadap al-Qur'an dan hadis sepotong-potong, tidak komprehensif (tidak menyeluruh) dan jauh dari bimbingan para ulama yang mumpuni dalam pengetahuan Agama Islam. Dengan demikian untuk mencegah terjadinya radikalisme agama dengan modelkekerasan, perluupaya: menyebar luaskan ajaran Islam yang benar dan konprehensif, khususnya mengenai hal hal yang sering disalah-pahami dan menimbulkan sikap radikal seperti tentang masalah hukum tagyirul munkar (merubah kemunkaran), tentang masalah hukum jihad fi sabilillah, dan tentang masalah hukum negara Republik Indonesia (bukan negara Islam), melakukan pendekatan rohani kepada generasi muda dan memberikan bimbingan keagamaan, sekali gus mengawasi mereka dari pihak pihak yang akan menyesatkan mereka, khususnya pendekatan oleh para kiyai atau pendidik dan harus dilakukan kordinasi dengan berbagai pihak yang terkait.

${ }^{29}$ Abdurrahman Wahid, 1994, Menjadikan Hukum sebagai Penunjang Pembangunan dalam Hukum Islam di Indonesia Pemikiran dan Praktek (Bandung: Remaja Rosdakarya, 1994), hlm. 2. 
Shobirin

\section{DFTAR PUSTAKA}

Arto, Mukti A., Peradilan Agama Dalam Sistem Ketatanegaraan Indonesia, Yogyakarta: Pustaka Pelajar, 2012.

al-Syathibi, al-Muwáafaqăt $\bar{f}$ Ușul al-Syariah, Kairo, Muṣtafa Muhammad, t.th.

Alfarisi, Salman, Mohammad Hatta Biografi Singkat 1902-1980, Yogyakarta: Garasi, 2009.

Asy'ari, Musa, Filsafat Islam Sunnah Nabi Dalam Berpikir, Yogyakarta: LESFI, 2002.

Amiruddin dan Asikin, Jaenal, Pengantar Metodologi Hukum, Jakarta: Raja Grafindo Persada, 2004.

Azra, Azumardi, Pergolakan Politik Islam dari Fundamentalisme, Modernisme, Hingga Post-Engineering, Jakarta: Paramadina, 1996.

Ahmad SF, Amrullah (eds), Dimensi Hukum Islam dalam Sistem Hukum Nasional, Jakarta: Gema Insani Pers, 1996.

ash-Shiddieqy, Hasbi, Peradilan dan Hukum Acara Islam, Semarang: Pustaka Rizki Putra, 1997.

asy'ari, Musa, Filsafat Islam Sunnah Nabi Dalam Berpikir, Yogyakarta: LESFI, 2002.

Bisri, Cik Hasan, Peradilan Agama di Indonesia, Jakarta: Raja Grafindo Persada, 1998.

Darji Darmodiharjo dan Sidharta, Pokok-pokok Filsafat Hukum, Apa dan Bagaimaan Filsafat Hukum Indonesia, Jakarta: Gramedia Pustaka Utama, 2002.

Haq, Hamka, al-Syatibi Aspek Teologis Konsep Mashlalah dalam Kitab al- Muwafaqat, Jakarta: Erlangga, 2007.

Haryono, Anwar, Hukum Islam Keadilan dan Keluasannya, Jakarta: Bulan Bintang, 2004.

Husein, Mochtar, Islam itu Indah Refleksi Keimanan, Yogyakarta: Pustaka Pelajar, 2008.

Kusumaatmadja, Mochtar, Fungsi dan Perkembangan Hukum dalam Pembangunan Nasional, Bandung: Bina Cipta, 1976. 
Mughni, A. Syafiq, Nilai-nilai Islam Perumusan Ajaran dan Upaya Aktualisasi, Yogyakarta: Pustaka Pelajar, 2001.

Mertokusumo Sudikno, Hukum Acara Perdata Indonesia, Yogyakarta: Liberty, 2002.

Madkur, Salam M., Al Qadla' fy al Islam, Kairo: Dar al-Nahdhah al-Arabiyah, t.th.

Manan, Abdul, Aspek-aspek Pengubah Hukum, Jakarta: Kencana Prenada Media. LP3ES, 2005.

Manan, Bagir, Kekuasaan Kehakiman Indonesia dalam UU No.4 Tabun 2004,Yogyakarta FH UII Press, 2007.

Mar'i, Hasan A., al-Ijtihäd fi Syari'ah al-IsTamiyyah, Kairo: Muṣafa Muhammad, 1976.

Prihadi, Kamus Pintar Bahasa Indonesia, Surabaya: Alfa, t.th.

Pound, Roscoe, Pengantar Filsafat Hukum, Jakarta: Bhatara, 1972.

Rahardjo, Satjioto, Hukum dalam Jagat Ketertiban, Jakarta: UKI Press, 2006.

Sumaryono E, Hermenentik Sebuah Metode Filsafat, Yogyakarta: Kanisius, 1993.

Usman, Muslih, Kaidah-kaidah Ushuliyyah dan Fiqhiyyah Pedoman Dasar dalam Istimbath Hukum Islam, Jakarta: Rajawali Press, 1997.

Wahid, Abdurrahman, Menjadikan Hukum sebagai Penunjang Pembangunan dalam Hukum Islam di Indonesia Pemikiran dan Praktek, Bandung: Remaja Rosdakarya, 1994.

Zaidan, Abdul Karim, Nizam al-Qada' fi al-Syariat al-Islamiyah, Baghdad: Aniy, 1984. 
Shobirin

Halaman ini tidak sengaja untuk dikosongkan 